\title{
PENGHAMBATAN PEMBUSUKAN "PRESS LIQUOR" DARI PENGOLAHAN TEPUNG IKAN DENGAN PERLAKUAN ASAM FORMIAT DAN PEMANASAN
}

\author{
Hari Eko Irianto"), Theresia Dwi Suryaningrum"), Suparno ") \\ dan Ijah Muljanah")
}

\begin{abstract}
ABSTRAK
Press liquor yang merupakan hasil samping pengolahan tepung ikan mudah sekali mengalami pembusukan. Penelitian ini ditujukan untuk mendapatkan cara pengolahan tepung ikanyang dapat menghambat proses pembusukan press liquor tersebut. Perlakuan-perlakuan yang diterapkan pada ikan sebelum pengepresan press liquor, yaitu (1) ikan direndam di dalam larutan asam formiat $3 \%$ selama 30 menit, (2) ikan dikukus selama 30 menit, (3) ikan direbus selama 30 menit, (4) ikan direndam di dalam larutan asam formiat 3\% selama 30 menit dan kemudian dikukus selama 30 menit, dan (5) ikan direndam dalam larutan asam formiat 3\% dan kemudian direbus selama 30 menit. Press liquor yang diperoleh dianalisis secara organoleptis, kimiawi dan mikrobiologis. Perlakuan perendaman ikan di dalam larutan asam dapat menghasilkan press liquor yang mempunyai nilai $\mathrm{pH}$, kandungan TVB dan TPC lebih rendah. Di samping itu perlakuan pengukusan cenderung menghasilkan press liquor dengan kandungan TBA lebih tinggi. Di dalam penelitian ini diperoleh kesimpulan bahwa kombinasi perlakuan perendaman dalam larutan asam dan pemanasan merupakan perlakuan yang terbaik, karena press liquor yang diperoleh mempunyai umur simpan lebih panjang dibandingkan dengan yang lain.
\end{abstract}

ABSTRACT : Inhibition of Deterioration of Press Liquor Obtained from Fish Meal Processing by Formic Acid and Heating Treatments, by: Hari Eko Irianto, Tberesia Dwi Suryaningrum, Suparno and Ijab Muljanab

Press liquor which is a by-product of fish meal processing easily deteriorates. This study is aimed to find a method of fish meal processing using formic acid and heating treatments, which could inhibit the deterioration of press liqour.

Treatments applied to the fish before pressing were (1) soaking in $3 \%$ formic acid solution for 30 minutes, (2) steaming for 30 minutes, (3) boiling for 30 minutes, (4) soaking in $3 \%$ formic acid solution and then steaming for 30 minutes, and (5) soaking in $3 \%$ formic acid and then boiling for 30 minutes. Press liquor obtained were analyzed organoleptically, chemically and microbiologically.

Formic acid soaking induced lower $\mathrm{pH}$ value, TVB content and TPC of press liquor. However, steaming treatment showed a tendency to produce press liquor with higher TBA value. This study recommends that the combination treatments of formic acid soaking and heating to be applied in the fish meal processing, since this treatment resulted in press liquor showing the longest shelf-life.

KEYWORDS: Fish meal, press liqour, formic acid, heating process

\section{PENDAHULUAN}

Proses pengolahan tepung ikan tradisional dengan cara pengolahan dan peralatan yang sangat sederhana telah berkembang pesat di Negara (Bali) dan Muncar (Banyuwangi, Jawa Timur). Tahap-tahap pengolahan yang biasa dilakukan adalah perebusan ikan, pengepresan dan pengeringan. Pada tahap 
pengepresan dihasilkan cairan yang terdiri dari air, minyak, protein dan serpihan daging ikan. Cairan tersebut biasanya disebut sebagai "press liquor". Selain itu dihasilkan padatan ikan yang dikenal sebagai "press cake". Press liquor dan bersama-sama dengan air perebus biasanya dibuang ke selokan yang mengalir melewati daerah pemukiman dan dapat menimbulkan permasalahan berupa bau busuk, terutama pada musim kemarau.

Dalam rangka mengatasi hal tersebut, penelitian ini ditujukan untuk mencari metode pengolahan tepung ikan yang dapat menghasilkan cairan tidak mudah busuk. Bila dalam penelitian ini diperoleh hasil yang menunjukkan bahwa perlakuan-perlakuan yang diuji dapat menghambat pembusukan press liquor, berarti ini akan memberi peluang kemungkinan untuk melakukan penyimpanan press liquor sebelum dipisahkan minyaknya atau sebelum dilakukan pengolahan limbah. Selain itu, bila press liquor dibuang ke saluran umum, risiko pencemaran bau di sekitar tempat pengolahan akan berkurang.

Hipotesis yang digunakan sebagai dasar pertimbangan untuk pelaksanaan penelitian adalah bahwa perlakuan asam dan pemanasan terhadap ikan selama pengolahan tepung ikan dapat menghambat proses pembusukan yang terjadi pada press liquor yang dihasilkan.

Di dalam penelitian ini akan diteliti kemungkinan penggunaan perlakuan perendaman bahan mentah ikan di dalam larutan asam formiat 3\% serta perlakuan perebusan dan pengukusan untuk memperpanjang daya awet press liquor yang dihasilkan dari pengolahan tepung ikan tradisional. Asam formiat dapat menurunkan $\mathrm{pH}$ dari press liquor sehingga dapat mengurangi kemungkinan bagi bakteri pembusuk untuk tumbuh. Selain itu penurunan $\mathrm{pH}$ sampai pada titik isoelektrik protein akan dapat membantu proses pemisahan minyak. Asam formiat telah digunakan pada pembuatan silase ikan (Kompiang, 1977; Arifudin dan Murtini, 1993) dan silase limbah kodok (Yunizal et al., 1994), dan ternyata berhasil menahan terjadinya pembusukan terhadap ikan dan limbah kodok. Adapun pemanasan akan menyebabkan terjadinya koagulasi protein sehingga akan mempermudah proses pemisahan cairan pada saat pengepresan. Selain itu pemanasan dapat menyebabkan kematian bakteri selama pengolahan, sehingga jumlah bakteri yang mungkin terdapat pada press liquor dapat dikurangi.

\section{BAHAN DAN METODE}

\section{Bahan}

Bahan mentah yang digunakan adalah ikan lemuru (Sardinella longiceps) yang diperoleh dari TPI Muncar, Banyuwangi dengan tingkat kesegaran yang baik. Ikan tersebut dibawa ke Instalasi Penelitian Perikanan Laut Slipi Jakarta dalam peti berpendingin es. 


\section{Metode}

\section{- Persiapan sampel}

Kombinasi perlakuan yang diterapkan terhadap ikan lemuru selama pengolahan adalah sebagai berikut:

a. Ikan direndam dalam larutan asam formiat $3 \%$ selama 30 menit, dan kemudian dipres;

b. Ikan tanpa direndam dalam larutan asam dikukus selama 30 menit, dan kemudian dipres;

c. Ikan tanpa direndam dalam larutan asam direbus selama 30 menit, dan kemudian dipres;

d. Ikan direndam dalam larutan asam formiat $3 \%$ selama 30 menit dikukus selama 30 menit, dan kemudian dipres;

e. Ikan direndam dalam larutan asam formiat 3\% selama 30 menit direbus selama 30 menit, dan kemudian dipres.

Pada setiap perlakuan digunakan ikan sebanyak $5 \mathrm{~kg}$. Untuk pengamatan daya awet, press liquor yang diperoleh dari setiap perlakuan tersebut disimpan pada suhu kamar. Setiap sampel dibuat dengan dua kali ulangan.

\section{- Analisis}

Dari setiap pengepresan, press liquor dan press cake yang diperoleh ditimbang untuk menentukan rendemen masing-masing. Selama penyimpanan, press liquor diamati secara organoleptis, kimiawi dan mikrobiologis. Pengamatan organoleptis dilakukan terhadap penampakan, warna dan bau dengan memberikan deskripsi dari sampel. Analisis kimia yang dilaksanakan adalah kadar air, TVB, TBA, $\mathrm{NH}_{3}$, dan $\mathrm{pH}$ dengan metode Anonimous (1974). Sedangkan analisis mikrobiologi meliputi TPC yang dikerjakan dengan menggunakan metode Fardiaz (1987).

\section{HASIL DAN PEMBAHASAN}

\section{Rendemen Press Cake dan Press Liquor}

Rendemen press cake dan press liquor yang dihasilkan dari setiap perlakuan dapat dilihat pada Tabel 1.

Hasil tersebut menunjukkan bahwa perlakuan perendaman ikan dalam larutan asam formiat dan penggunaan panas dapat meningkatkan efektivitas pengepresan dalam rangka membebaskan sisa-sisa cairan (press liquor). Pengolahan dengan hanya menggunakan perlakuan perendaman ikan di dalam larutan asam tanpa kombinasi dengan perlakuan pemanasan merupakan 
perlakuan yang tidak efektif dan menghasilkan press liquor dengan jumlah yang rendah.

Tabel 1. Press cake dan press liquor yang dihasilkan dari setiap perlakuan (\%) Table 1. Yields of press cake and press liquor from each treatment (\%)

\begin{tabular}{lcc}
\hline \hline \multicolumn{1}{c}{ Perbluan (Treatment) } & Press Cake $(\%)$ & Press Liquor (\%) \\
\hline Perendaman asam (Acid soaking) & 70,0 & 30,0 \\
Segar + kukus (Fresh + steaming) & 47,1 & 52,9 \\
Segar + rebus (Fresh + boiling) & 50,0 & 50,0 \\
Perendaman asam + kukus (Acid soaking + & 45,7 & 54,3 \\
steaming) & & \\
Perendaman asam + rebus (Acid soaking + boiling) & 40,0 & 60,0 \\
\hline \hline
\end{tabular}

Kombinasi perlakuan perendaman ikan di dalam larutan asam dengan panas dapat meningkatkan jumlah press liquor yang dibebaskan. Perlakuan perendaman dalam larutan asam dan panas akan mengakibatkan denaturasi protein (Winarno, 1984), yang akhirnya berpengaruh terhadap jumlah cairan yang dibebaskan dari jaringan daging ikan. Perlakuan pengukusan dan perebusan saja tidak menunjukkan perbedaan yang nyata terhadap jumlah press liquor yang dibebaskan.

\section{Perubahan-Perubahan Press Liquor Selama Penyimpanan}

\section{- Perubahan-perubahan organoleptis}

Hasil pengamatan terhadap perubahan-perubahan penampakan, warna dan bau dari press liquor selama penyimpanan dapat dilihat pada Lampiran 1. Pengamatan organoleptik menunjukkan bahwa umur simpan press liquor dari masing-masing perlakuan adalah 36 jam untuk press liquor dari ikan yang hanya mendapat perlakuan perendaman dalam larutan asam formiat $3 \%$ selama 30 menit dan juga untuk press liquor dari ikan yang hanya mendapat perlakuan perebusan selama 30 menit; 12 jam untuk press liquor dari ikan yang hanya mendapat perlakuan pengukusan; 108 jam untuk press liquor dari ikan yang mendapat perlakuan kombinasi antara perendaman di dalam larutan asam formiat $3 \%$ selama 30 menit dan pemanasan; baik pengukusan maupun perebusan.

\section{(1) Penampakan dan warna}

Press liquor yang dihasilkan dari pengolahan dengan perlakuan perendaman ikan di dalam larutan asam tanpa perlakuan pemanasan, pada awalnya berbentuk emulsi berwarna coklat tua. Warna coklat tua tersebut diakibatkan 
oleh darah yang terikut press liquor pada saat pengepresan. Mulai jam ke-4 penyimpanan, press liquor terpisah menjadi tiga bagian, yaitu emulsi berwarna coklat pada bagian atas, kemudian cairan dan endapan pada bagian bawah. Sampai akhir penyimpanan press liquor tetap terpisah menjadi tiga bagian tersebut, tetapi warnanya menjadi kehitaman. Minyak tetap tidak terpisah dari emulsi. Diduga protein yang ada pada press liquor dapat bertindak sebagai emulsifier yang baik, sehingga menyebabkan minyak tidak terpisah dari emulsi.

Mulai jam ke-16 penyimpanan, permukaan press liquor dari pengolahan yang hanya mendapat perlakuan perendaman dalam larutan asam telah ditumbuhi oleh jamur, walaupun masih berupa koloni-koloni kecil. Akhirnya pada jam penyimpanan ke-36, seluruh permukaan press liquor telah ditumbuhi oleh jamur.

Press liquor yang diperoleh dari pengolahan dengan perlakuan pemanasan, baik untuk ikan yang sebelumnya direndam dalam larutan asam formiat maupun tidak, pada awal penyimpanan terpisah menjadi dua bagian, yaitu lapisan minyak ikan pada bagian atas dan emulsi pada bagian bawah. Pada penyimpanan lebih lanjut, press liquor terpisah menjadi empat bagian, yaitu minyak ikan, emulsi, cairan dan endapan. Selama penyimpanan lapisan emulsi semakin sedikit, sedangkan lapisan minyak ikan dan cairan semakin bertambah banyak. Hal ini dapat terjadi karena emulsi yang ada sangat tidak stabil, sehingga minyak ikan dan cairan dapat dengan mudah terpisah dengan sendirinya.

Mulai penyimpanan jam ke-8 sampai jam ke-20, pada permukaan press liquor dijumpai adanya busa yang diduga sebagai akibat dari aktivitas bakteri, terutama bakteri pembusuk. Pada akhir penyimpanan, press liquor yang didapat dari perlakuan perebusan dan tanpa perlakuan perendaman dalam larutan asam ditumbuhi jamur. Sedangkan untuk press liquor dari perlakuan pengukusan dengan atau tanpa perendaman dalam larutan asam dan perlakuan perebusan dengan perendaman dalam larutan asam tidak ditumbuhi jamur sampai akhir penyimpanan. Dengan perlakuan ini, perubahan warna selama penyimpanan tidak menyolok. Minyak, cairan dan endapan yang dihasilkan berwarna kuning atau oranye.

\section{(2) Bau}

Press liquor dari pengolahan dengan hanya mendapat perlakuan perendaman dalam larutan asam agak berbau asam. Tetapi dengan semakin lama penyimpanan, bau asam makin menghilang dan bau minyak ikan kemudian lebih menonjol. Pada saat jamur mulai tumbuh di permukaan, bau apek mulai timbul dan pada akhir penyimpanan (jam ke-36), bau apek mendominasi bau press liquor tersebut.

Bau awal (penyimpanan jam ke-0) press liquor yang diperoleh dari pengolahan dengan perlakuan pemanasan adalah seperti bau ikan rebus. Pada: penyimpanan jam ke empat bau ikan rebus mulai hilang dan digantikan oleh 
bau minyak ikan. Pada akhir penyimpanan, press liquor yang berasal dari pengolahan yang mendapat perlakuan pemanasan dengan dan tanpa perlakuan perendaman dalam larutan asam menunjukkan bau yang berbeda. Press liquor dari perlakuan pemanasan tanpa perlakuan perendaman dalam larutan asam berbau busuk pada akhir penyimpanan, yaitu jam ke-12 untuk perlakuan pengukusan dan jam ke-36 untuk perlakuan perebusan. Sedangkan untuk press liquor yang mendapat perlakuan pemanasan dan dikombinasi dengan perlakuan perendaman dalam larutan asam berbau tengik pada akhir penyimpanan (jam ke-108).

\section{Perubahan-perubahan kimiawi}

\section{(1) Kandungan TVB (Total Volatile Bases/Basa-basa Menguap Total)}

Secara umum kandungan TVB press liquor yang diperoleh dari semua perlakuan cenderung meningkat selama penelitian (Tabel 2). Hal ini sejalan dengan proses kerusakkan atau pembusukan dari press liquor.

Penggunaan perlakuan perendaman bahan mentah ikan dalam larutan asam cenderung dapat menekan proses peningkatan kandungan TVB, hal ini diduga akibat adanya hambatan terhadap aktivitas bakteri yang disebabkan oleh rendahnya $\mathrm{pH}$ dari press liquor (Tabel 2).

Tabel 2. Perubahan kadungan TVB press liquor selama penyimpanan (mgN\%) Table 2. TVB content changes in press liquor during storage ( $m g N \%$ )

\begin{tabular}{|c|c|c|c|c|c|c|c|c|c|}
\hline \multirow[t]{2}{*}{ Perlikinan / Treasment } & \multicolumn{9}{|c|}{ Penyimpanan (jam) / Storage (bovrs) } \\
\hline & 0 & 4 & 8 & 12 & 16 & 20 & 24 & 36 & 108 \\
\hline $\begin{array}{l}\text { Perendaman asam (Acid } \\
\text { soaking) }\end{array}$ & 43.51 & 42.89 & 45.58 & 56.35 & 52.21 & 50.14 & 63.67 & 68.79 & - \\
\hline $\begin{array}{l}\text { Segar + Kukus } \\
\text { (Fresh+Steaming) }\end{array}$ & 36.77 & $\begin{array}{c}38.54 \\
\cdot\end{array}$ & 59.21 & 67.13 & $\cdot$ & $\cdot$ & $\cdot$ & $\cdot$ & $\cdot$ \\
\hline Segar + Rebus (Fresh + Boiling) & 41.43 & 48.15 & 54.65 & 77.0 & 84.54 & 71.74 & 95.51 & 139.81 & - \\
\hline $\begin{array}{l}\text { Asam + Kukus } \\
(\text { Acid }+ \text { Steaming })\end{array}$ & 31.91 & 44.75 & 35.88 & 49.12 & 50.55 & 58.85 & 61.86 & - & 96.97 \\
\hline Asam + Rebus (Acid+Boiling) & 22.40 & 32.74 & 43.73 & 45.21 & 54.16 & 63.98 & 71.28 & $\cdot$ & 93.16 \\
\hline
\end{tabular}

Hasil ini menunjukkan bahwa penggunaan asam dapat menurunkan kecepatan dekomposisi protein dan derivatnya menjadi basa-basa mudah menguap. 


\section{(2) Nilai TBA (Thiobarbituric Acid)}

Pada awal penyimpanan (jam ke-0), nilai TBA dari press liquor yang dihasilkan dari proses pengolahan dengan perlakuan pengukusan lebih besar dibandingkan dengan yang lain (Tabel 3 ).

Tabel 3. Perubahan nilai TBA press liquor selama penyimpanan $(\mu \mathrm{mol} / \mathrm{kg})$

Table 3. TBA value changes in press liquor during storage ( $\mu \mathrm{mol} / \mathrm{kg})$

\begin{tabular}{|c|c|c|c|c|c|c|c|c|c|}
\hline \multirow[t]{2}{*}{ Perblkuan / Treament } & \multicolumn{9}{|c|}{ Penyimpanan (jam) / Storage (bours) } \\
\hline & 0 & 4 & 8 & 12 & 16 & 20 & 24 & 36 & 108 \\
\hline $\begin{array}{l}\text { Perendaman asam (Acid } \\
\text { soaking) }\end{array}$ & 73.53 & 93.19 & 138.9 & 102.1 & 123.0 & 121.7 & 166.8 & 262.7 & - \\
\hline $\begin{array}{l}\text { Segar + Kukus } \\
(\text { Fresh }+ \text { Steaming })\end{array}$ & 308.1 & 37.81 & 62.91 & 40.11 & - & - & - & $\cdot$ & - \\
\hline Segar + Rebus $($ Fresh + Boiling $)$ & 21.4 & 28.96 & 45.62 & 44.33 & 50.41 & 60.51 & 77.86 & 71.05 & - \\
\hline $\begin{array}{l}\text { Asam + Kukus } \\
\text { (Acid+Steaming) }\end{array}$ & 231.7 & 141.0 & 145.4 & 141.9 & 157.9 & 47.14 & 70.88 & $\cdot$ & 77.68 \\
\hline Asam+Rebus (Acid+Boiling) & 28.22 & 48.38 & 53.70 & 30.21 & 53.07 & 57.81 & 62.92 & - & 46.06 \\
\hline
\end{tabular}

Diduga selama pengukusan terjadi proses pembentukan malonaldehid dari hidroperoksida yang cepat. Oksigen yang kontak langsung dengan lipid yang ada pada daging ikan menyebabkan proses oksidasi yang menghasilkan hidroperoksida. Hidroperoksida yang terbentuk kemungkinan lebih banyak dibandingkan dengan yang terbentuk pada press liquor yang didapat dari pengolahan dengan perebusan. Pada proses perebusan, ikan dilindungi oleh air dari kontak langsung dengan oksigen yang ada di udara, kecuali dengan oksigen yang larut dalam air, sehingga proses oksidasi dapat dibatasi. Dengan demikian malonaldehid yang terbentuk juga terbatas.

Nilai TBA dari press liquor yang dihasilkan dari perlakuan perendaman ikan dalam larutan asam formiat tanpa kombinasi dengan perlakuan pemanasan meningkat selama penyimpanan. Kecenderungan serupa juga ditemui pada press liquor yang diperoleh dari pengolahan tepung ikan yang melalui proses perebusan, baik yang dikombinasi dengan perlakuan perendaman dalam larutan asam maupun tidak, tetapi nilainya berfluktuasi. Nilai TBA tergantung pada kecepatan proses pembentukan malonaldehid dari hidroperoksida dan kecepatan reaksi antara malonaldehid dengan asam-asam amino, peptida dan senyawa-senyawa lain hasil dekomposisi protein (Erickson dan Bowers, 1976; Kwon et al., 1965; Finley, 1985). 


\section{(3) Kandungan $\mathrm{NH}_{3}$}

Kandungan $\mathrm{NH}_{3}$ (amonia) dari semua sampel berfluktuasi selama penyimpanan (Tabel 4).

Tabel 4. Perubahan kandungan $\mathrm{NH}_{3}$ press liquor selama penyimpanan (\%) Table 4. $\mathrm{NH}_{3}$ content changes in press liquor during storage (\%)

\begin{tabular}{|c|c|c|c|c|c|c|c|c|c|}
\hline \multirow[t]{2}{*}{ Perlakuan / Treatment } & \multicolumn{9}{|c|}{ Penyimpanan (jam) / Storege (bours) } \\
\hline & 0 & 4 & 8 & 12 & 16 & 20 & 24 & 36 & 108 \\
\hline $\begin{array}{l}\text { Perendaman asam (Acid } \\
\text { soaking) }\end{array}$ & 0.16 & 0.12 & 0.09 & 0.07 & 0.01 & $0: 43$ & 0.12 & 0.34 & - \\
\hline $\begin{array}{l}\text { Segar }+ \text { Kukus } \\
\text { (Fresh }+ \text { Steaming) }\end{array}$ & 0.28 & 0.35 & 0.33 & 0.14 & - & $\cdot$ & $\cdot$ & - & $\cdot$ \\
\hline Segar + Rebus $($ Fresh + Boiling) & 0.20 & 0.20 & 0.03 & 0.70 & 0.03 & 0.01 & 0.45 & 0.60 & - \\
\hline $\begin{array}{l}\text { Asam + Kukus } \\
\text { (Acid+Steaming) }\end{array}$ & 0.20 & 0.22 & 0.24 & 0.12 & 0.22 & 0.24 & 0.33 & $\cdot$ & 0.06 \\
\hline Asam + Rebus (Acid +Boiling) & 0.21 & 0.22 & 0.11 & 0.13 & 0.03 & 0.18 & 0.11 & - & 0.06 \\
\hline
\end{tabular}

Terjadinya fluktuasi tersebut dipengaruhi oleh kecepatan pembentukan $\mathrm{NH}_{3}$ sebagai hasil dekomposisi protein dan derivatnya oleh aktivitas bakteri (Zaitsev et al., 1969) dan kecepatan penguapan amonia.

Jumlah amonia yang terbentuk pada press liquor yang diperoleh dari pengolahan dengan hanya perlakuan perendaman dalam larutan asam lebih rendah dibandingkan dengan kandungan amonia press liquor dari perlakuan lainnya. Nilai pH yang rendah pada press liquor tersebut telah menyebabkan jumlah bakteri yang tumbuh pada sampel tersebut rendah, sehingga aktivitas yang diakibatkannya menghasilkan jumlah amonia yang lebih rendah.

\section{(4) $\mathbf{p H}$}

Perlakuan perendaman asam menghasilkan press liquor dengan $\mathrm{pH}$ yang lebih rendah dibandingkan dengan press liquor yang dalam pengolahannya tidak mendapatkan perlakuan tersebut (Tabel 5).

Nilai $\mathrm{pH}$ untuk press liquor dari ikan yang hanya mendapat perlakuan perendaman dalam larutan asam tidak menunjukkan perubahan yang nyata selama penyimpanan. Kemungkinan pembentukan senyawa-senyawa yang bersifat basa mampu menetralisir asam yang terbentuk selama penyimpanan akibat aktivitas bakteri. Sedangkan untuk press liquor yang diperoleh melalui pengolahan dengan perlakuan perendaman dalam larutan asam dan selanjutnya mendapat perlakuan pemanasan, nilai $\mathrm{pH}$-nya cenderung menurun secara 
perlahan sampai penyimpanan jam ke-24 dan kemudian meningkat pada akhir penyimpanan.

Tabel 5. Perubahan $\mathrm{pH}$ press liquor selama penyimpanan

Table 5. pH changes in press liquor during storage

\begin{tabular}{|c|c|c|c|c|c|c|c|c|c|}
\hline \multirow[t]{2}{*}{ Perlakum / Treatment } & \multicolumn{9}{|c|}{ Penyimpanan (jam) / Storage (bosers) } \\
\hline & 0 & 4 & 8 & 12 & 16 & 20 & 24 & 36 & 108 \\
\hline $\begin{array}{l}\text { Perendaman asam (Acid } \\
\text { soaking) }\end{array}$ & 4.9 & 5.0 & 4.8 & 5.0 & 4.8 & 4.8 & 4.8 & 5.0 & - \\
\hline $\begin{array}{l}\text { Segar + Kukus } \\
\text { (Fresh+Steaming })\end{array}$ & 6.3 & 5.5 & 5.3 & 5.9 & $\cdot$ & - & - & - & - \\
\hline Segar + Rebus (Fres $b+$ Boiling $)$ & 6.3 & 5.6 & 5.2 & 5.7 & 6.1 & 6.3 & 6.3 & 6.6 & - \\
\hline $\begin{array}{l}\text { Asam + Kukus } \\
(\text { Acid + Steaming })\end{array}$ & 5.4 & 5.4 & 5.0 & 5.2 & 5.1 & 5.1 & 4.8 & - & 5.2 \\
\hline Asam + Rebus (Acid + Boiling) & 5.5 & 5.3 & 5.2 & 5.1 & 5.0 & 5.1 & 4.9 & - & 5.4 \\
\hline
\end{tabular}

Nilai $\mathrm{pH}$ press liquor dari pengolahan tepung ikan yang hanya dengan perlakuan pemanasan (pengukusan dan perebusan) menurun secara drastis sampai penyimpanan jam ke-8 dan kemudian cenderung meningkat pada penyimpanan lebih lanjut.

\section{Perubahan-Perubahan Kandungan Total Koloni Bakteri (TPC)}

Sejalan dengan proses pembusukan dari press liquor, kandungan TPC dari semua sampel cenderung meningkat selama penyimpanan seperti yang diperlihatkan pada Tabel 6.

Penerapan perlakuan perendaman ikan dalam larutan asam formiat $3 \%$ menghasilkan press liquor dengan kandungan TPC yang lebih rendah dibandingkan dengan press liquor yang diperoleh dari pengolahan tanpa perlakuan perendaman dalam larutan asam. Seperti yang telah diterangkan sebelumnya bahwa perlakuan perendaman ikan di dalam larutan asam dapat menghasilkan press liquor dengan nilai $\mathrm{pH}$ yang lebih rendah dan hal ini dapat mempengaruhi pertumbuhan bakteri. Menurut Jay (1978) pada umumnya mikroorganisma akan tumbuh baik pada $\mathrm{pH}$ sekitar 7,0; yaitu 6,6-7,5. Pangan yang mempunyai $\mathrm{pH}$ rendah cenderung lebih tahan terhadap serangan mikroorganisma dibandingkan dengan yang mempunyai $\mathrm{pH}$ netral (Frazier dan Westhoff, 1979). 
Tabel 6. Perubahan TPC press liquor selama penyimpanan Table 6. TPC content changes in press liquor during storage

\begin{tabular}{|c|c|c|c|c|c|c|c|c|c|}
\hline \multirow[t]{2}{*}{ Perialuan / Treatinent } & \multicolumn{9}{|c|}{ Peryimpanan (jam) / storege (boars) } \\
\hline & 0 & 4 & 8 & 12 & 16 & 20 & 24 & 36 & 108 \\
\hline Perendaman asam (Acid soaking) & $5.0 \times 10^{4}$ & $2.0 \times 10^{4}$ & $5.0 \times 10^{3}$ & $2.0 \times 10^{3}$ & $3.0 \times 10^{4}$ & $3.5 \times 10^{6}$ & $1.2 \times 10^{8}$ & $2.0 \times 10^{8}$ & - \\
\hline Segar + Kukus (Fresb + Steaming) & $4.3 \times 10^{5}$ & $1.2 \times 10^{6}$ & $2.8 \times 10^{6}$ & $1.9 \times 10^{6}$ & - & - & - & - & - \\
\hline Segar + Rebus (Fresb + Boiling) & $2.5 \times 10^{5}$ & $1.7 \times 10^{6}$ & $2.0 \times 10^{6}$ & $1.5 \times 10^{5}$ & $1.8 \times 10^{6}$ & $1.2 \times 10^{8}$ & $2.2 \times 10^{8}$ & $1.0 \times 10^{9}$ & - \\
\hline Asam + Kukus (Acid + Steaming $)$ & $1.7 \times 10^{5}$ & $5.0 \times 10^{4}$ & $1.4 \times 10^{5}$ & $4.0 \times 10^{4}$ & $8.0 \times 10^{4}$ & $9.0 \times 10^{6}$ & $2.1 \times 10^{8}$ & - & $2.0 \times 10^{9}$ \\
\hline Asam + Rebus (Acid + Boiling $)$ & $2.0 \times 10^{4}$ & $5.0 \times 10^{3}$ & $6.0 \times 10^{4}$ & $6.0 \times 10^{4}$ & $6.0 \times 10^{3}$ & $5.0 \times 10^{7}$ & $1.9 \times 10^{8}$ & . & $2.6 \times 10^{9}$ \\
\hline
\end{tabular}

\section{KESIMPULAN}

Perlakuan perendaman ikan dalam larutan asam saja tidak efektif digunakan untuk pengolahan tepung ikan tradisional, khususnya untuk pelepasan press liquor. Metode yang lebih efektif dapat diperoleh melalui kombinasi dengan perlakuan panas.

Perlakuan perendaman ikan di dalam larutan asam dapat menurunkan $\mathrm{pH}$ dari press liquor yang sekaligus dapat menurunkan total bakteri yang terdapat pada press liquor. Dengan demikian perlakuan ini dapat menghambat proses pembusukan press liquor dan sekaligus dapat meningkatkan umur simpan dari press liquor yang dihasilkan. Bila metode ini diadopsi oleh pengolah tradisional akan sangat bermanfaat, karena dapat mengurangi kemungkinan pencemaran bau selama penanganan press liquor sebelum dilakukan proses lebih lanjut.

\section{DAFTAR PUSTAKA}

Anonimous, 1974. Metode dan prosedur analisis kimiawi hasil perikanan, Lembaga Teknologi Perikanan, Jakarta

Arifudin R. dan Murtini, J.T., 1992. Silase ikan, di dalam Kumpulan hasil-hasil penelitian pasca panen perikanan, Puslitbang Perikanan, Jakarta:146-148

Erickson D.R. dan Bowers R.H., 1976. Objective determination of fat stability in prepared foods, di dalam Objective methods for food evaluation: Proceeding of a symposium, National Academic of Science, Washington, D.C.:133-144

Fardiaz S., 1987. Penuntun praktek: Mikrobiologi pangan, Lembaga Sumber daya Informasi, IPB, Bogor

Finley J.W., 1985. Environmental effects on protein quality, di dalam Chemical changes in food during processing, Ed. Richardson, T dan Finley, J.W., The AVI publishing Co.Inc., Westport, Connecticut 
Frazier W.C. dan Westhoff D.C., 1979. Food microbiology, Tata McGraw-Hill Publishing Co Inc, New Delhi

Jay J.M., 1978. Modern food microbiology $2^{\text {nd }}$ edition, van Nostrand Reindhold Company, New York

Kompiang I.P., 1977. III. Nilai gizi dari silase ikan yang dibuat dengan penambahan asam format, J.Pen.Tek.Hasil Perik. 2: 34-39

Kwon T.W., Menzel D.B. dan Olcott H.S., 1965. Reactivity of malonaldehyde with food constituents, J.Food Scie. 30: 808-813

Winarno F.G., 1984. Kimia pangan dan gizi, PT Gramedia, Jakarta

Yunizal, H.E.Irianto dan I.Muljanah, 1994. Pemakaian berbagai jenis asam pada pembuatan silase limbah kodok, J.Pen.Pasca Panen Perik. 82: 16-23

Zaisev V., Kizetter I., Lagunov L., Morakova T., Minder L. dan Podsevalov V., 1969. Fish curing and processing, MIR Publishing, Moscow 
Lampiran I. Deskripsi organoleptik press liquor selama penyimpanan

a. Perlakuan Perendaman Asam

\begin{tabular}{|c|c|c|}
\hline $\begin{array}{l}\text { Lama } \\
\text { Penyimpanan } \\
\text { (jam) }\end{array}$ & Penampakan Dan Warna & Bau \\
\hline 0 & $\begin{array}{l}\text { Berbentuk emulsi berwarna coklat, tak ada } \\
\text { bagian yang terpisah }\end{array}$ & Agak asam \\
\hline 4 & $\begin{array}{l}\text { Terpisah menjadi dua bagian, bagian atas } \\
\text { emulsi berwarna coklat kehitaman, bagian } \\
\text { bawah coklat kekuningan dan terdapat } \\
\text { endapan pada bagian bawah }\end{array}$ & $\begin{array}{l}\text { Sedikit } \\
\text { asam }\end{array}$ \\
\hline 8 & $\begin{array}{l}\text { Terdiri dari tiga lapisan, bagian atas berupa } \\
\text { emulsi berwarna coklat, kemudian cairan } \\
\text { berwarna coklat dan endapan berwarna } \\
\text { coklat }\end{array}$ & $\begin{array}{l}\text { Sedikit } \\
\text { asam }\end{array}$ \\
\hline 12 & $\begin{array}{l}\text { Terdiri dari tiga lapisan, bagian atas } \\
\text { berbentuk emulsi berwarna coklat, cairan } \\
\text { berwarna coklat dan endapan }\end{array}$ & $\begin{array}{l}\text { Bau minyak } \\
\text { ikan }\end{array}$ \\
\hline 16 & $\begin{array}{l}\text { Pada bagian atas mulai ditumbuhi jamur, } \\
\text { terdiri dari tiga lapisan, yaitu emulsi, cairan } \\
\text { dan endapan yang kesemuanya berwarna } \\
\text { coklat }\end{array}$ & $\begin{array}{l}\text { Bau minyak } \\
\text { ikan }\end{array}$ \\
\hline 20 & $\begin{array}{l}\text { Pada bagian atas ditumbuhi jamur, terdiri } \\
\text { dari tiga lapisan, yaitu bagian atas berupa } \\
\text { emulsi, cairan dan endapan yang } \\
\text { kesemuanya berwarna coklat }\end{array}$ & $\begin{array}{l}\text { Bau minyak } \\
\text { ikan dan } \\
\text { agak apek }\end{array}$ \\
\hline 24 & $\begin{array}{l}\text { Pada bagian atas ditumbuhi jamur, terdiri } \\
\text { dari tiga lapisan, yaitu bagian atas berupa } \\
\text { emulsi, cairan dan endapan yang } \\
\text { kesemuanya berwarna coklat kehijauan }\end{array}$ & $\begin{array}{l}\text { Bau minyak } \\
\text { ikan dan } \\
\text { agak apek }\end{array}$ \\
\hline 28 & $\begin{array}{l}\text { Sama dengan penyimpanan pada jam ke-24 } \\
\text { tetapi berwarna coklat tua. }\end{array}$ & Bau apek \\
\hline 36 & $\begin{array}{l}\text { Permukaan telah penuh ditumbuhi jamur, } \\
\text { terdiri dari } 3 \text { lapisan seperti pada } \\
\text { penyimpanan jam ke-28, tetapi warnanya } \\
\text { kehitaman }\end{array}$ & Bau apek \\
\hline
\end{tabular}




\section{b. Pêrlakuan Pengukusan Tanpa Perendaman Asam}

\begin{tabular}{c|l|l}
\hline $\begin{array}{c}\text { Penyimpanan } \\
\text { (jam) }\end{array}$ & $\begin{array}{l}\text { Penampakan Dan Warna } \\
\text { Terpisah menjadi dua bagian, bagian atas } \\
\text { berupa minyak berwarna coklat, dan bagian } \\
\text { bawah emulsi berwarna coklat tua } \\
\text { Terdiri dari dua bagian, bagian atas minyak } \\
\text { berwarna kuning muda, dan bagian bawah } \\
\text { emulsi berwarna coklat muda } \\
8\end{array}$ & $\begin{array}{l}\text { Bau air } \\
\text { rebusan } \\
\text { terdiri dari tiga lapisan, yaitu lapisan atas } \\
\text { berupa minyak, kemudian cairan dan } \\
\text { endapan, semua berwarna oranye } \\
\text { Bagian atas berbusa, terdiri dari lapisan } \\
\text { minyak pada bagian atas, kemudian terdapat } \\
\text { lapisan emulsi, cairan dan endapan yang } \\
\text { kesemuanya berwarna oranye }\end{array}$
\end{tabular}


c. Perlakuan Perebusan Tanpa Perendaman Asam

\begin{tabular}{|c|c|c|}
\hline $\begin{array}{l}\text { Lama } \\
\text { Penyimpanan } \\
\text { (jam) }\end{array}$ & Penampakan Dan Warna & Bau \\
\hline 0 & $\begin{array}{l}\text { Terpisah menjadi dua bagian, bagian atas } \\
\text { terdiri dari minyak yang berwarna oranye } \\
\text { dan bagian bawah berupa emulsi berwarna } \\
\text { coklat }\end{array}$ & $\begin{array}{l}\text { Bau air } \\
\text { rebusan }\end{array}$ \\
\hline 4 & $\begin{array}{l}\text { Pada bagian atas sedikit berbusa, bagian atas } \\
\text { terdiri dari minyak berwarna kuning, } \\
\text { kemudian cairan berwarna kuning keemasan } \\
\text { dan ada bagian endapan pada bagian bawah }\end{array}$ & Bau minyak \\
\hline 8 & $\begin{array}{l}\text { Terdapat busa pada bagian atas, kemudian } \\
\text { terdapat lapisan-lapisan minyak, cairan dan } \\
\text { endapan berwarna oranye }\end{array}$ & $\begin{array}{l}\text { Bau minyak } \\
\text { ikan dan } \\
\text { sedikit asam }\end{array}$ \\
\hline 12 & $\begin{array}{l}\text { Terdapat busa pada bagian atas, kemudian } \\
\text { terdapat lapisan-lapisan minyak, cairan dan } \\
\text { endapan yang berwarna oranye }\end{array}$ & $\begin{array}{l}\text { Bau minyak } \\
\text { ikan dan } \\
\text { sedikit asam }\end{array}$ \\
\hline 16 & $\begin{array}{l}\text { Terdapat busa pada bagian permukaan, } \\
\text { terdiri atas lapisan-lapisan minyak, emulsi, } \\
\text { cairan dan endapan yang semua berwarna } \\
\text { oranye }\end{array}$ & $\begin{array}{l}\text { Bau minyak } \\
\text { ikan dan } \\
\text { sedikit asam }\end{array}$ \\
\hline 20 & $\begin{array}{l}\text { Terdapat busa pada bagian permukaan, } \\
\text { terdiri dari lapisan-lapisan minyak, cairan } \\
\text { dan endapan yang semuanya berwarna } \\
\text { oranye }\end{array}$ & $\begin{array}{l}\text { Bau minyak } \\
\text { ikan dan } \\
\text { sedikit asam }\end{array}$ \\
\hline 24 & $\begin{array}{l}\text { Terdapat sedikit busa pada bagian } \\
\text { permukaan, terdiri atas lapisan-lapisan } \\
\text { minyak dan cairan berwarna putih serta } \\
\text { endapan berwarna oranye }\end{array}$ & $\begin{array}{l}\text { Bau minyak } \\
\text { ikan dan agak } \\
\text { tengik }\end{array}$ \\
\hline 28 & $\begin{array}{l}\text { Terdiri dari lapisan-lapisan minyak, cairan } \\
\text { dan endapan berwarna oranye }\end{array}$ & Bau busuk \\
\hline 36 & $\begin{array}{l}\text { Pada bagian permukaan ditumbuhi jamur, } \\
\text { warna lapisan minyak, cairan dan endapan } \\
\text { oranye }\end{array}$ & Bau busuk \\
\hline
\end{tabular}




\section{d. Perlakuan Pengukusan Dengan Perendaman Asam}

\begin{tabular}{|c|c|c|}
\hline $\begin{array}{l}\text { Lama } \\
\text { Penyimpanan } \\
\text { (jam) }\end{array}$ & Penampakan Dan Warna & Bau \\
\hline 0 & $\begin{array}{l}\text { Terpisah menjadi dua bagian, bagian atas } \\
\text { terdiri dari minyak berwarna coklat, bagian } \\
\text { bawah berupa emulsi berwarna coklat tua }\end{array}$ & $\begin{array}{l}\text { Bau air } \\
\text { rebusan }\end{array}$ \\
\hline 4 & $\begin{array}{l}\text { Terdiri atas tiga lapisan, yaitu lapisan } \\
\text { minyak berwarna kuning keemasan pada } \\
\text { bagian atas, kemudian cairan berwarna } \\
\text { kuning muda, dan endapan. }\end{array}$ & Agak netral \\
\hline 8 & $\begin{array}{l}\text { Terdiri atas empat lapisan, yaitu terdiri dari } \\
\text { minyak, emulsi, cairan dan endapan yang } \\
\text { semua berwarna oranye }\end{array}$ & $\begin{array}{l}\text { Agak minyak } \\
\text { ikan }\end{array}$ \\
\hline 12 & $\begin{array}{l}\text { Terdiri atas empat lapisan, yaitu minyak, } \\
\text { emulsi, cairan dan endapan yang semuanya } \\
\text { berwarna oranye }\end{array}$ & $\begin{array}{l}\text { Agak minyak } \\
\text { ikan }\end{array}$ \\
\hline 16 & $\begin{array}{l}\text { Pada bagian atas terdapat busa, terdiri atas } \\
\text { empat lapisan, yaitu minyak, emulsi, cairan } \\
\text { dan endapan yang semuanya berwarna } \\
\text { oranye }\end{array}$ & $\begin{array}{l}\text { Bau minyak } \\
\text { ikan }\end{array}$ \\
\hline 20 & $\begin{array}{l}\text { Pada bagian terdapat buih, terdiri atas empat } \\
\text { bagian, yaitu minyak, emulsi, cairan dan } \\
\text { endapan yang semuanya berwarna oranye }\end{array}$ & $\begin{array}{l}\text { Bau minyak } \\
\text { ikan }\end{array}$ \\
\hline 24 & $\begin{array}{l}\text { Terdiri atas empat lapisan, yaitu minyak, } \\
\text { emulsi, cairan dan endapan yang semuanya } \\
\text { berwarna oranye }\end{array}$ & $\begin{array}{l}\text { Bau minyak } \\
\text { ikan }\end{array}$ \\
\hline 28 & $\begin{array}{l}\text { Terdiri atas lapisan-lapisan minyak, } \\
\text { kemudian emulsi, cairan dan endapan yang } \\
\text { semua berwarna oranye }\end{array}$ & $\begin{array}{l}\text { Bau minyak } \\
\text { ikan }\end{array}$ \\
\hline 36 & $\begin{array}{l}\text { Terdiri atas lapisan-lapisan minyak, } \\
\text { kemudian emulsi, cairan dan endapan yang } \\
\text { semua berwarna oranye }\end{array}$ & $\begin{array}{l}\text { Bau minyak } \\
\text { ikan }\end{array}$ \\
\hline 108 & $\begin{array}{l}\text { Terdiri atas empat lapisan, yaitu minyak } \\
\text { yang berwarna oranye, lapisan emulsi, cairan } \\
\text { oranye dan endapan }\end{array}$ & Bau tengik \\
\hline
\end{tabular}


e. Perlakuan Perebusan Dengan Perendaman Asam

\begin{tabular}{|c|c|c|}
\hline $\begin{array}{l}\text { Lama } \\
\text { Penyimpanan } \\
\text { (jam) }\end{array}$ & Penampakan Dan Warna & Bau \\
\hline 0 & $\begin{array}{l}\text { Terpisah menjadi dua bagian, bagian atas } \\
\text { terdiri dari minyak berwarna oranye, bagian } \\
\text { bawah berupa emulsi berwarna coklat }\end{array}$ & $\begin{array}{l}\text { Bau ikan } \\
\text { rebus }\end{array}$ \\
\hline 4 & $\begin{array}{l}\text { Terdiri atas dua lapisan, yaitu berupa } \\
\text { minyak berwarna kuning muda dan emulsi } \\
\text { berwarna coklat, terdapat endapan pada } \\
\text { bagian bawah }\end{array}$ & Bau minyak \\
\hline 8 & $\begin{array}{l}\text { Terdiri dari empat lapisan, yaitu minyak, } \\
\text { emulsi, cairan dan endapan yang berwarna } \\
\text { coklat }\end{array}$ & $\begin{array}{l}\text { Bau minyak } \\
\text { ikan }\end{array}$ \\
\hline 12 & $\begin{array}{l}\text { Terdiri atas empat lapisan, yaitu minyak } \\
\text { yang berwarna kekuningan, emulsi, cairan } \\
\text { dan endapan }\end{array}$ & $\begin{array}{l}\text { Bau minyak } \\
\text { ikan }\end{array}$ \\
\hline 16 & $\begin{array}{l}\text { Terdapat buih pada bagian permukaan, } \\
\text { terdiri atas empat lapisan, yaitu minyak, } \\
\text { emulsi, cairan dan endapan yang semuanya } \\
\text { berwarna oranye }\end{array}$ & $\begin{array}{l}\text { Bau minyak } \\
\text { ikan }\end{array}$ \\
\hline 20 & $\begin{array}{l}\text { Terdiri atas empat lapisan, yaitu minyak, } \\
\text { emulsi, cairan dan endapan yang semuanya } \\
\text { berwarna kuning }\end{array}$ & $\begin{array}{l}\text { Bau minyak } \\
\text { ikan }\end{array}$ \\
\hline 24 & $\begin{array}{l}\text { Terdiri atas empat lapisan, yaitu minyak, } \\
\text { emulsi, cairan kehijauan dan endapan } \\
\text { berwarna keputihan }\end{array}$ & $\begin{array}{l}\text { Bau minyak } \\
\text { yang agak } \\
\text { tengik }\end{array}$ \\
\hline 28 & $\begin{array}{l}\text { Terdiri atas lapisan-lapisan minyak, } \\
\text { kemudian emulsi, cairan dan endapan yang } \\
\text { semua berwarna oranye }\end{array}$ & $\begin{array}{l}\text { Bau minyak } \\
\text { ikan yang } \\
\text { agak tengik }\end{array}$ \\
\hline 36 & $\begin{array}{l}\text { Terdiri atas lapisan-lapisan minyak, } \\
\text { kemudian emulsi, cairan dan endapan yang } \\
\text { semua berwarna oranye }\end{array}$ & $\begin{array}{l}\text { Bau minyak } \\
\text { ikan agak } \\
\text { tengik }\end{array}$ \\
\hline 108 & $\begin{array}{l}\text { Terdiri atas empat lapisan, yaitu minyak } \\
\text { yang berwarna oranye, lapisan emulsi, cairan } \\
\text { kuning dan endapan }\end{array}$ & Bau tengik \\
\hline
\end{tabular}

